\title{
Recent advances in epilepsy genomics and genetic testing
}

\section{[version 1; peer review: 2 approved]}

\author{
Malavika Hebbar, Heather C. Mefford (D) \\ Division of Genetic Medicine, Department of Pediatrics, University of Washington, Seattle, WA, 98105, USA
}

V1 First published: 12 Mar 2020, 9(F1000 Faculty Rev):185

https://doi.org/10.12688/f1000research.21366.1

Latest published: 12 Mar 2020, 9(F1000 Faculty Rev):185

https://doi.org/10.12688/f1000research.21366.1

\section{Abstract}

Developmental and epileptic encephalopathies (DEEs) are a group of severe, early onset epilepsies characterized by refractory seizures, developmental delay or regression associated with ongoing epileptic activity, and generally poor prognosis. DEE is genetically and phenotypically heterogeneous, and there is a plethora of genetic testing options to investigate the rapidly growing list of epilepsy genes. However, more than $50 \%$ of patients with DEE remain without a genetic diagnosis despite state-of-the-art genetic testing. In this review, we discuss the major advances in epilepsy genomics that have surfaced in recent years. The goal of this review is to reach a larger audience and build a better understanding of pathogenesis and genetic testing options in DEE.

\section{Keywords}

Whole genome sequencing, Gene panels, Next generation sequencing, Developmental and epileptic encephalopathy, Epilepsy, Novel genes, Chromosomal microarray, Genetic testing

\section{Open Peer Review}

Approval Status

1

2

version 1

12 Mar 2020

Faculty Reviews are review articles written by the prestigious Members of Faculty Opinions. The articles are commissioned and peer reviewed before publication to ensure that the final, published version is comprehensive and accessible. The reviewers who approved the final version are listed with their names and affiliations.

\section{Josemir W. Sander, UCL Queen Square} Institute of Neurology, London, UK

2. Weiping Liao, Institute of Neuroscience and the Second Affiliated Hospital of Guangzhou Medical University, Guangzhou, China

Any comments on the article can be found at the end of the article. 
Corresponding author: Heather C. Mefford (hmefford@uw.edu)

Author roles: Hebbar M: Data Curation, Writing - Original Draft Preparation; Mefford HC: Conceptualization, Resources, Supervision, Writing - Review \& Editing

Competing interests: No competing interests were disclosed.

Grant information: The author(s) declared that no grants were involved in supporting this work.

Copyright: $\odot 2020$ Hebbar M and Mefford HC. This is an open access article distributed under the terms of the Creative Commons Attribution License, which permits unrestricted use, distribution, and reproduction in any medium, provided the original work is properly cited.

How to cite this article: Hebbar M and Mefford HC. Recent advances in epilepsy genomics and genetic testing [version 1; peer review: 2 approved] F1000Research 2020, 9(F1000 Faculty Rev):185 https://doi.org/10.12688/f1000research.21366.1

First published: 12 Mar 2020, 9(F1000 Faculty Rev):185 https://doi.org/10.12688/f1000research.21366.1 


\section{Background}

The developmental and epileptic encephalopathies (DEEs) are a heterogeneous group of severe, early onset conditions characterized by developmental delay or regression associated with refractory seizures and generally poor prognosis ${ }^{1}$. The incidence of epilepsy is nearly 70 per 100,000 children younger than 2 years and genetic epilepsies account for more than $0.4 \%$ of the general population constituting $30 \%$ of all epilepsies ${ }^{2}$. The prevalence of epilepsy in the United States is 5-8 million subjects annually, while the incidence is $35-71 / 100,000$ per year ${ }^{3}$, though epidemiological data specific for DEEs are just emerging. A study on a broader group of severe epilepsies beginning before 18 months found an incidence of one in 2,000 births ${ }^{4-6}$. Some of the most well-studied DEEs include infantile spasms and Dravet, Lennox-Gastaut, and West syndromes.

Over the last decade, next-generation sequencing (NGS) has advanced the field of human genetics and genomics significantly ${ }^{7}$, leading to an explosion of gene discovery across many human disorders. The number of disease-associated genes has grown to 4,132 , and over 50 genes have been newly associated with epilepsy in the last three years alone ${ }^{8}$. However, the new technologies have also brought new challenges? ${ }^{9}$. The ability to perform sequencing across large cohorts of affected individuals with variable but related phenotypes highlights "phenotype expansions" associated with some disease genes. For the epilepsies, patients can have clinical presentations that range from static to degenerative, clouding a clear distinction between isolated DEEs and secondary epilepsies associated with neurodevelopmental disorders (NDDs) ${ }^{10}$. A great benefit of using NGS is its ability to deliver clinical diagnosis in a short time, but the available "cafeteria choice" of cutting-edge genetic tests can leave medical professionals and patients' families confused.

In this review, we discuss the major advances in epilepsy genomics that have surfaced in recent years and summarize the pros and cons of genetic testing options in DEEs that could help clinicians and patients reach the end of their "diagnostic odyssey" faster and in a cost-effective way.

\section{Genetic testing}

DEE is genetically and phenotypically heterogeneous, and there is a plethora of genetic testing options ranging from gene panels, which may include a few or hundreds of genes, to exome sequencing (ES), which investigates all $\sim 20,000$ genes. These are NGS techniques, also known as massive parallel sequencing (MPS), which include a variety of approaches that facilitate simultaneous sequencing of a large number of DNA segments ${ }^{11}$. Whole ES and targeted gene panels have contributed incredibly towards novel gene discovery, particularly in the pediatric epilepsies $^{12}$. Sequencing all three billion bases of the genome, genome sequencing (GS), is mostly done in research settings but will inevitably enter the clinical realm soon.

Copy-number variants (CNVs) contribute significantly to variation in the human genome. CNVs are estimated to cause $1.2 \%$ difference for every reference genome ${ }^{13}$. CNVs can be detected by several genomic methods including conventional karyotype (deletions/duplications $>5 \mathrm{Mb}$ ) and chromosomal microarrays (CMA, $\sim 100 \mathrm{~kb}-5 \mathrm{Mb}$ ). Other methods such as quantitative PCR and multiplex ligation-dependent probe amplification are targeted approaches to detect smaller variations $(<1 \mathrm{~kb})$.

The most common types of genetic causes of DEE are sequence changes, responsible for $30-40 \%$ of cases, and chromosomal deletions or duplications, responsible for 5-10\% of cases ${ }^{14,15}$. Gene panels provide a higher sequencing depth and lower cost when compared to ES and GS but restrict the diagnosis to specific genes in the panel. Importantly, some large panels are based on ES, with restricted analysis of only the "panel" genes, so the benefit of higher depth of coverage is lost, but this opens up the possibility of future reanalysis to include the whole exome. ES also provides good sequencing depth at a lower cost; however, it is restricted to protein coding regions only. CNVs can be predicted by this method but require a secondary method to plot the breakpoints. Selection of the most appropriate test may depend on a variety of factors including age at seizure onset, severity of disease, other associated features, and patient insurance.

\section{Novel genes in DEE}

Several novel genes and disorders associated with DEE have been identified in the last few years ${ }^{16-18}$ (Table 1). Many of the genes causing epilepsy encode components of neuronal ion channels leading to neuronal hyperexcitability or depletion of inhibitory mechanisms ${ }^{19,20}$. However, recently, several new genes coding for proteins other than ion channels have been identified, such as chromatin remodelers, intracellular signaling molecules, metabolic enzymes, transcription factors, and mitochondrial complex genes ${ }^{5,21,22}$. The search term "epilepsy" OR "seizure" OR "epileptic syndrome" OR "epileptic encephalopathy" from 2016 to 2019 led to 66 entries in Online Mendelian Inheritance in Man. Although comprehensive discussion of all the discoveries is beyond the scope of this review, selected major advances are highlighted below.

ES trios have revealed the influence of de novo mutations as a genetic cause of severe epilepsies (Table 1). A recent study compared de novo variants identified in individuals with variable NDDs with and without epilepsy ${ }^{23}$. In the subset of 1,942 subjects with NDDs with epilepsy, 33 genes were observed to have significant excess of de novo variants, three of which had limited or no previous evidence of disease association: CACNAIE, SNAP25, and GABRB2. Nine de novo missense and two truncating variants in CACNA1E variants were identified in this cohort $^{23}$. In a subsequent study, de novo variants in CACNAIE were identified in 30 individuals with $\mathrm{DEE}^{16}$. Detailed phenotyping revealed refractory infantile-onset seizures, severe hypotonia, and profound developmental delay, often with congenital contractures, hyperkinetic movement disorders, macrocephaly, and early death ${ }^{16}$. Functional analysis revealed consistent gain-of-function effects in R-type calcium channels. Some patients were seizure free on treatment with the anti-epileptic drug topiramate, which blocks $\mathrm{R}$-type calcium channels. The condition is now catalogued as early infantile epileptic encephalopathy type 69 (\#MIM 618285).

The RORB gene, which encodes the retinoid-related nuclear receptor ROR-beta, was recently associated with photosensi- 
Table 1. Epilepsy genes and phenotypes catalogued in Online Mendelian Inheritance in Man (OMIM) since 2016.

\begin{tabular}{|c|c|c|}
\hline Gene & Phenotype & $\begin{array}{l}\text { OMIM } \\
\text { phenotype \# }\end{array}$ \\
\hline \multicolumn{3}{|c|}{ Chromatin remodeling } \\
\hline$A C T L 6 B$ & Epileptic encephalopathy, early infantile, 76 & \#618470 \\
\hline SMARCC2 & Coffin-Siris syndrome 8 & \#618362 \\
\hline STAG2 & Neurodevelopmental disorder, X-linked, with craniofacial abnormalities & \#301022 \\
\hline \multicolumn{3}{|c|}{ Intracellular signaling } \\
\hline CSF1R & Brain abnormalities, neurodegeneration, and dysosteosclerosis & \#618476 \\
\hline YWHAZ & Popov-Chang syndrome & \#618428 \\
\hline CHP1 & Spastic ataxia 9, autosomal recessive & \#618438 \\
\hline \multicolumn{3}{|c|}{ Ion channels and neurotransmitter receptors } \\
\hline CACNA1E & Epileptic encephalopathy, early infantile, 69 & \#618285 \\
\hline GABRG2 & Epileptic encephalopathy, early infantile, 74 & \#618396 \\
\hline CACNA2D2 & Cerebellar atrophy with seizures and variable developmental delay & \#618501 \\
\hline HCN1 & Generalized epilepsy with febrile seizures plus, type 10 & \#618482 \\
\hline CACNA1B & Neurodevelopmental disorder with seizures and nonepileptic hyperkinetic movements & \#618497 \\
\hline KCNK4 & $\begin{array}{l}\text { Facial dysmorphism, hypertrichosis, epilepsy, intellectual/developmental delay, and gingival } \\
\text { overgrowth syndrome }\end{array}$ & \#618381 \\
\hline SLC25A42 & Metabolic crises, recurrent, with variable encephalomyopathic features and neurologic regression & \#618416 \\
\hline ATP1A1 & Hypomagnesemia, seizures, and mental retardation 2 & \#618314 \\
\hline SLC28A1 & Uridine-cytidineuria & \#618477 \\
\hline SCN8A & Myoclonus, familial, 2 & \#618364 \\
\hline SLC9A7 & Intellectual developmental disorder, X-linked 108 & \#301024 \\
\hline \multicolumn{3}{|l|}{ Metabolism } \\
\hline GLS & Epileptic encephalopathy, early infantile, 71 & \#618328 \\
\hline PARS2 & Epileptic encephalopathy, early infantile, 75 & \#618437 \\
\hline RNF13 & Epileptic encephalopathy, early infantile, 73 & \#618379 \\
\hline FCSK & Congenital disorder of glycosylation with defective fucosylation 2 & \#618324 \\
\hline PPPЗCA & Arthrogryposis, cleft palate, craniosynostosis, and impaired intellectual development & \#618265 \\
\hline PPP2CA & Neurodevelopmental disorder and language delay with or without structural brain abnormalities & \#618354 \\
\hline MTHFS & Neurodevelopmental disorder with microcephaly, epilepsy, and hypomyelination & \#618367 \\
\hline P4HTM & $\begin{array}{l}\text { Hypotonia, hyperventilation, impaired intellectual development, dysautonomia, epilepsy, and eye } \\
\text { abnormalities }\end{array}$ & \#618493 \\
\hline DHPS & Neurodevelopmental disorder with seizures and speech and walking impairment & \#618480 \\
\hline MAST1 & Mega-corpus-callosum syndrome with cerebellar hypoplasia and cortical malformations & \#618273 \\
\hline DEGS1 & Leukodystrophy, hypomyelinating, 18 & \#618404 \\
\hline MYORG & Basal ganglia calcification, idiopathic, 7 , autosomal recessive & \#618317 \\
\hline ALKBH8 & Intellectual developmental disorder, autosomal recessive 71 & \#618504 \\
\hline NAXD & Encephalopathy, progressive, early onset, with brain edema and/or leukoencephalopathy, 2 & \#618321 \\
\hline KDM6B & Neurodevelopmental disorder with coarse facies and mild distal skeletal abnormalities & \#618505 \\
\hline HS6ST2 & Paganini-Miozzo syndrome & \#301025 \\
\hline TRMT1 & Intellectual developmental disorder, autosomal recessive 68 & \#618302 \\
\hline COLGALT1 & Brain small vessel disease 3 & \#618360 \\
\hline IREB2 & Neurodegeneration, early-onset, with choreoathetoid movements and microcytic anemia & \#618451 \\
\hline
\end{tabular}




\begin{tabular}{|c|c|c|}
\hline Gene & Phenotype & $\begin{array}{l}\text { OMIM } \\
\text { phenotype \# }\end{array}$ \\
\hline$P I G B$ & Epileptic encephalopathy, early infantile, 80 & \#618580 \\
\hline \multicolumn{3}{|c|}{ Mitochondrial metabolism } \\
\hline MICOS13 & Combined oxidative phosphorylation deficiency 37 & \#618329 \\
\hline GFM2 & Combined oxidative phosphorylation deficiency 39 & \#618397 \\
\hline \multicolumn{3}{|c|}{ Neuronal development } \\
\hline NFASC & Neurodevelopmental disorder with central and peripheral motor dysfunction & \#618356 \\
\hline NHLRC2 & Fibrosis, neurodegeneration, and cerebral angiomatosis & \#618278 \\
\hline \multicolumn{3}{|c|}{ Nucleoplasmic transport } \\
\hline NUP133 & Galloway-Mowat syndrome 8 & \#618349 \\
\hline NUP214 & Susceptibility to acute infection-induced encephalopathy 9 & \#618426 \\
\hline \multicolumn{3}{|c|}{ Regulation of cell morphology and motility } \\
\hline BICD2 & Spinal muscular atrophy, lower extremity-predominant, $2 \mathrm{~b}$, prenatal onset, autosomal dominant & \#618291 \\
\hline DOCK3 & Neurodevelopmental disorder with impaired intellectual development, hypotonia, and ataxia & \#618292 \\
\hline PHACTR1 & Epileptic encephalopathy, early infantile, 70 & \#618298 \\
\hline MACF1 & Lissencephaly 9 with complex brainstem malformation & \#618325 \\
\hline DYNC112 & Neurodevelopmental disorder with microcephaly and structural brain anomalies & \#618492 \\
\hline \multicolumn{3}{|c|}{ Synaptic vesicle cycle } \\
\hline NEUROD2 & Epileptic encephalopathy, early infantile, 72 & \#618374 \\
\hline MAPK8IP3 & Neurodevelopmental disorder with or without variable brain abnormalities & \#618443 \\
\hline \multicolumn{3}{|c|}{ Transcriptional regulation } \\
\hline ATN1 & Congenital hypotonia, epilepsy, developmental delay, and digital anomalies & \#618494 \\
\hline$R O R B$ & Susceptibility to idiopathic generalized epilepsy 15 & \#618357 \\
\hline ZNF142 & Neurodevelopmental disorder with impaired speech and hyperkinetic movements & \#618425 \\
\hline RSRC1 & Intellectual developmental disorder, autosomal recessive 70 & \#618402 \\
\hline TCF2O & Developmental delay with variable intellectual impairment and behavioral abnormalities & \#618430 \\
\hline EIF3F & Intellectual developmental disorder, autosomal recessive 67 & \#618295 \\
\hline ZBTB11 & Intellectual developmental disorder, autosomal recessive 69 & \#618383 \\
\hline CNOT1 & Holoprosencephaly 12 with or without pancreatic agenesis & \#618500 \\
\hline NFIB & Macrocephaly, acquired, with impaired intellectual development & \#618286 \\
\hline SOX4 & Coffin-Siris syndrome 10 & \#618506 \\
\hline TRRAP & Developmental delay with or without dysmorphic facies and autism & \#618454 \\
\hline \multicolumn{3}{|c|}{ Others Transmembrane protein } \\
\hline TMEM94 & Intellectual developmental disorder with cardiac defects and dysmorphic facies & \#618316 \\
\hline \multicolumn{3}{|c|}{ Structural protein } \\
\hline COL3A1 & Polymicrogyria with or without vascular-type Ehlers-Danlos syndrome & \#618343 \\
\hline \multicolumn{3}{|c|}{ Nuclear DNA polymerase } \\
\hline POLE & $\begin{array}{l}\text { Intrauterine growth retardation, metaphyseal dysplasia, adrenal hypoplasia congenita, genital } \\
\text { anomalies, and immunodeficiency }\end{array}$ & \#618336 \\
\hline \multicolumn{3}{|c|}{ Multiple functions } \\
\hline WDR4 & Microcephaly, growth deficiency, seizures, and brain malformations & \#618346 \\
\hline \multicolumn{3}{|c|}{ Intracellular trafficking } \\
\hline TRAPPC2L & Encephalopathy, progressive, early onset, with episodic rhabdomyolysis & \#618331 \\
\hline
\end{tabular}


tive generalized epilepsy in a large family segregating a nonsense variant in the gene ${ }^{24}$. In the same study, two individuals with de novo coding variants in $R O R B$ and a third individual with a de novo intragenic deletion presented with significant developmental delays and behavioral abnormalities in addition to their generalized epilepsy, consistent with a diagnosis of DEE. Together, these results suggest that RORB haploinsufficiency causes a fairly consistent epilepsy phenotype but variable developmental outcomes.

Several additional recent discoveries highlight the overlap between DEEs and NDDs, with several new genes associated with syndromic epilepsy, including NBEA, FBXO11, and SMARCC2 $2^{25-27}$. $N B E A$ has long been a candidate gene for NDDs and autism ${ }^{28}$. Clear disease association and description of the phenotypic spectrum were recently reported after the identification of 24 de novo variants in patients with NDD, many of whom also had generalized epilepsy. Similarly, one-quarter to one-third of individuals with pathogenic variants in FBXO11 or SMARCC2, each associated with variable NDD, also have epilepsy.

Recessive genes are a rare but important cause of DEE. Inborn errors of metabolism and malformations of cortical development constitute most of the autosomal recessive epilepsies ${ }^{29}$. Glycosylphosphatidylinositol (GPI) anchored proteins play key roles in the human body, mainly in development and neurogenesis. Several genes involved in GPI biosynthesis and the remodeling pathway are causative of autosomal recessive epilepsy. One such gene that was recently identified is $P_{I G B^{30}}$. This group reported 16 patients from 10 unrelated families with early infantile epileptic encephalopathy, type 80 (\#MIM 618580). Some other recessive epileptic encephalopathies are due to WWOX, TBC1D24, UBA5, and SLC13A5 $5^{31-34}$. $T B C 1 D 24$ is known to cause a continuum of features that were originally described as distinct, recognized Mendelian phenotypes ranging from autosomal dominant deafness to autosomal recessive epileptic encephalopathy ${ }^{35}$. Similarly, in addition to causing epileptic encephalopathy type 28 (\#MIM 616211), WWOX is implicated as the molecular basis

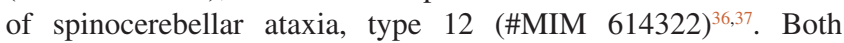
these genes are examples of a spectrum of disorders with increasingly blurred lines differentiating them as more individuals and pathogenic variants are identified. Recently, homozygous pathogenic variants in $C S F 1 R$, encoding a tyrosine kinase growth factor receptor for colony-stimulating factor-1, were identified in patients with brain abnormalities, neurodegeneration, and dysosteosclerosis ${ }^{38}$. This gene was previously implicated in a dominant adult-onset leukoencephalopathy. Proliferation and growth of macrophages, including microglia, require colony-stimulating factor-1 receptor (CSF1R). This study represents an under-recognized group of genes that are associated with well-described, dominant phenotypes but can also produce a different clinical picture when present in biallelic, recessive states. This is important for filtering and interpreting variants from NGS data, as candidate variants cannot be eliminated based on poor phenotypic $\mathrm{fit}^{39}$.

\section{CNVs in DEE}

Studies using CMA have shown that pathogenic CNVs account for $5-10 \%$ of childhood epilepsies including $\mathrm{DEE}^{40-42}$, and CMA is the recommended first-line genetic test if the clinical picture includes dysmorphism, intellectual disability, congenital anomalies, and other neuropsychiatric features ${ }^{43}$. However, NGS is increasingly being employed in the detection of CNVs. One good example is the detection of deletions in TANGO2. TANGO proteins play a crucial role in redistributing Golgi membranes into the endoplasmic reticulum $^{44}$. Bi-allelic TANGO2 pathogenic variants have been identified as a cause of a pediatric condition with multi-organ involvement ${ }^{45}$. Recently, a study identified intragenic, multi-exon deletions in TANGO2 by reanalysis of ES data ${ }^{45,46}$. The most common disease-causing allele $(55 \%)$ in one series was deletion of exons 3-9 of TANGO2 ${ }^{17}$. ES is not yet a match for CMA for $\mathrm{CNV}$ detection, as it can provide data about only the protein coding or exonic regions, but it is an increasingly powerful diagnostic tool, and a growing number of algorithms are being developed to aid the detection of CNVs by NGS. With the introduction of ES and GS, it is now possible to detect both single nucleotide variations and CNVs using an exome- or genome-wide approach with a single test ${ }^{47}$.

\section{Future of epilepsy genomics}

Despite state-of-the-art genetic testing, more than $50 \%$ of patients with DEE remain without a genetic diagnosis. Whole GS is increasingly being used to uncover the role of non-coding genetic material in the human genome ${ }^{48,49}$. Undoubtedly, massively parallel sequencing has greatly accelerated disease gene (and variant) discovery, but most studies and nearly all clinical testing employ gene panels or ES, limiting the genomic search space and the types of variants that can potentially be identified. For disorders like fragile $\mathrm{X}$ syndrome that are due to the expansion of triplet repeats, testing strategies other than gene panels or exome are required. Several studies have proposed a genetic testing strategy to achieve the highest clinical utility, cost-effectiveness, and diagnostic yield for individuals with epilepsy $\mathrm{y}^{50-52}$, but specific testing algorithms are likely to change over time as new tests are introduced and the costs of existing tests decrease. New assays may be required to detect lesser-known but important molecular mechanisms.

Post-zygotic, somatic mosaic mutations are increasingly identified as an important cause of genetic disorders ${ }^{22,53}$. In epilepsies, many of the mutations in the mTOR pathway that lead to brain malformations are somatic mosaic mutations. Typically, leukocyte-derived DNA is used in individuals with DEE to search for germline variants, which are inherited or arise de novo in the zygote. Recent studies have demonstrated that post-zygotic somatic variants also underlie $\mathrm{DEE}^{22,54-58}$ but can be easily missed by standard NGS tests.

Another field that has potential to uncover some of the underlying molecular mechanisms is epigenetics. Epimutations represent a class of mutational event where the epigenetic status of a genomic locus deviates significantly from the normal state ${ }^{59}$. Methylation of DNA and histone modifications are increasingly being implicated as causative or contributing factors for several conditions ${ }^{60,61}$. DNA methylation at $\mathrm{CpG}$ dinucleotides is the most widely studied epigenetic modification. Methylation represents an epigenetic change-a chemical modification of DNA that does not change the underlying 
DNA sequence. A recent study investigated the role of de novo methylation changes in NDDs using methylation chips $^{62}$. In a cohort of 489 affected individuals, of which $16 \%$ had epilepsy, the authors identified rare differential methylation in $23 \%$ of cases when compared to controls. When the parents were able to be tested, $\sim 40 \%$ of the methylation variants were de novo, suggesting that de novo methylation abnormalities may be causative in $5-10 \%$ of their cohort. When identified, the underlying causes of the methylation changes were varied and included CNVs, sequence variants in regulatory elements, or repeat expansions, each of which is easily missed by conventional (even next-generation) sequencing methods. In a second study of undiagnosed NDDs using a similar approach ${ }^{63}$, candidate differentially methylated regions in two individuals with epilepsy and intellectual disability of unknown etiology were identified.

Several techniques that enable longer read lengths (up to 200 $\mathrm{kb}$ ), such as nanopore-based "fourth-generation" sequencing ${ }^{64}$ and single molecule, real time (SMRT) sequencing ${ }^{65}$, have recently emerged. The advantages of long reads include shorter sequencing time, ability to sequence AT- or GC-rich regions and repeat stretches, and the detection of large structural abnormalities including insertions, deletions, inversions, translocations, and tandem/interspersed regions ${ }^{66,67}$.

\section{Conclusion}

NGS-based technologies are a mainstay of clinical diagnostic testing, and the applications and testing options will only increase as the technology, bioinformatics, and resources evolve. NGS successfully detects single nucleotide variations, structural rearrangements, and CNVs. Clinical phenotypes are now being defined by the underlying molecular basis. Interpretation of NGS data is an iterative process involving forward genetics along with a reverse phenotyping approach. The dynamic nature of data analysis should be explained to patients and their families. As more and more novel genetic and epigenetic etiologies are unveiled in DEE, the challenge for clinical and research laboratories is to make sure the testing is clinically relevant, is cost effective, and can be integrated into clinical care.
1. Berg AT, Berkovic SF, Brodie MJ, et al:: Revised terminology and concepts for organization of seizures and epilepsies: report of the ILAE Commission on Classification and Terminology, 2005-2009. Epilepsia. 2010; 51(4): 676-85. PubMed Abstract | Publisher Full Text

2. International League Against Epilepsy Consortium on Complex Epilepsies: Genetic determinants of common epilepsies: a meta-analysis of genome-wide association studies. Lancet Neurol. 2014; 13(9): 893-903. PubMed Abstract | Publisher Full Text | Free Full Text

3. Jacobs M, Jensen FE: Introduction to institute of medicine report: epilepsy across the spectrum: promoting health and understanding. Epilepsy Curr. 2012; 12(6): 243-4.

PubMed Abstract | Publisher Full Text | Free Full Text

4. Monlong J, Cossette $\mathrm{P}$, Meloche $\mathrm{C}$, et al.: Human copy number variants are enriched in regions of low mappability. Nucleic Acids Res. 2018; 46(14): 7236-49. PubMed Abstract | Publisher Full Text | Free Full Text

5. McTague A, Howell KB, Cross JH, et al:: The genetic landscape of the epileptic encephalopathies of infancy and childhood. Lancet Neurol. 2016; 15(3): 304-16. PubMed Abstract | Publisher Full Text

6. $\quad \mathrm{F}$ Howell KB, Eggers S, Dalziel K, et al:: A population-based cost-effectiveness study of early genetic testing in severe epilepsies of infancy. Epilepsia. 2018; 59(6): 1177-87.

PubMed Abstract | Publisher Full Text | Free Full Text | F1000 Recommendation

7. $\mathrm{F}$ Dunn $\mathrm{P}$, Albury CL, Maksemous N, et al.: Next Generation Sequencing Methods for Diagnosis of Epilepsy Syndromes. Front Genet. 2018; 9: 20. PubMed Abstract | Publisher Full Text | Free Full Text | F1000 Recommendation

8. F Bamshad MJ, Nickerson DA, Chong JX: Mendelian Gene Discovery: Fast and Furious with No End in Sight. Am J Hum Genet. 2019; 105(3): 448-55. PubMed Abstract | Publisher Full Text | Free Full Text | F1000 Recommendation

9. $\quad F$ Di Resta C, Galbiati S, Carrera P, et al.: Next-generation sequencing approach for the diagnosis of human diseases: open challenges and new opportunities. EJIFCC. 2018; 29(1): 4-14.

PubMed Abstract | Free Full Text | F1000 Recommendation

10. $F$ von Deimling M, Helbig I, Marsh ED: Epileptic Encephalopathies-Clinical Syndromes and Pathophysiological Concepts. Curr Neurol Neurosci Rep. 2017 17(2): 802.

PubMed Abstract | Publisher Full Text | F1000 Recommendation

11. Møller RS, Dahl HA, Helbig I: The contribution of next generation sequencing to epilepsy genetics. Expert Rev Mol Diagn. 2015; 15(12): 1531-8. PubMed Abstract | Publisher Full Text

12. EpiPM Consortium: A roadmap for precision medicine in the epilepsies. Lancet Neurol. 2015; 14(12): 1219-28.

PubMed Abstract | Publisher Full Text | Free Full Text
13. Pang AW, MacDonald JR, Pinto D, et al.: Towards a comprehensive structural variation map of an individual human genome. Genome Biol. 2010; 11(5): R52. PubMed Abstract | Publisher Full Text | Free Full Text

14. Helbig KL, Farwell Hagman KD, Shinde DN, et al.: Diagnostic exome sequencing provides a molecular diagnosis for a significant proportion of patients with epilepsy. Genet Med. 2016; 18(9): 898-905. PubMed Abstract | Publisher Full Text

15. Retterer K, Juusola J, Cho MT, et al:: Clinical application of whole-exome sequencing across clinical indications. Genet Med. 2016; 18(7): 696-704 PubMed Abstract | Publisher Full Text

16. Helbig KL, Lauerer RJ, Bahr JC, et al:: De Novo Pathogenic Variants in CACNA1E Cause Developmental and Epileptic Encephalopathy with Contractures, Macrocephaly, and Dyskinesias. Am J Hum Genet. 2019; 104(3): 562. PubMed Abstract | Publisher Full Text | Free Full Text

17. Dines JN, Golden-Grant K, LaCroix A, et al:: TANGO2: expanding the clinical phenotype and spectrum of pathogenic variants. Genet Med. 2019; 21(3): 601-7.

PubMed Abstract | Publisher Full Text | Free Full Text

18. Salpietro V, Dixon CL, Guo H, et al:: AMPA receptor GluA2 subunit defects are a cause of neurodevelopmental disorders. Nat Commun. 2019; 10(1): 3094. PubMed Abstract | Publisher Full Text | Free Full Text

19. Kaplan DI, Isom LL, Petrou S: Role of Sodium Channels in Epilepsy. Cold Spring Harb Perspect Med. 2016; 6(6): pii: a022814.

PubMed Abstract | Publisher Full Text | Free Full Text

20. Villa C, Combi R: Potassium Channels and Human Epileptic Phenotypes: An Updated Overview. Front Cell Neurosci. 2016; 10: 81. PubMed Abstract | Publisher Full Text | Free Full Text

21. Mantegazza M, Rusconi R, Scalmani $P$, et al:: Epileptogenic ion channel mutations: from bedside to bench and, hopefully, back again. Epilepsy Res. 2010; 92(1): 1-29.

PubMed Abstract | Publisher Full Text

22. Myers $\mathrm{CT}$, Mefford HC: Advancing epilepsy genetics in the genomic era. Genome Med. 2015; 7: 91.

PubMed Abstract | Publisher Full Text | Free Full Text

23. $\mathrm{F}$ Heyne $\mathrm{HO}$, Singh $\mathrm{T}$, Stamberger $\mathrm{H}$, et al.: De novo variants in neurodevelopmental disorders with epilepsy. Nat Genet. 2018; 50(7): 1048-53. PubMed Abstract | Publisher Full Text | F1000 Recommendation

24. Rudolf G, Lesca G, Mehrjouy MM, et al.: Loss of function of the retinoid-related nuclear receptor (RORB) gene and epilepsy. Eur J Hum Genet. 2016; 24(12): 1761-70.

PubMed Abstract | Publisher Full Text | Free Full Text

25. Mulhern MS, Stumpel C, Stong N, et al:: NBEA: Developmental disease gene with early generalized epilepsy phenotypes. Ann Neurol. 2018; 84(5): 788-95. PubMed Abstract | Publisher Full Text | Free Full Text 
26. Gregor A, Sadleir LG, Asadollahi R, et al:: De Novo Variants in the F-Box Protein FBXO11 in 20 Individuals with a Variable Neurodevelopmental Disorder. $A m \mathrm{~J}$ Hum Genet. 2018; 103(2): 305-16.

PubMed Abstract | Publisher Full Text | Free Full Text

27. Machol K, Rousseau J, Ehresmann S, et al:: Expanding the Spectrum of BAFRelated Disorders: De Novo Variants in SMARCC2 Cause a Syndrome with Intellectual Disability and Developmental Delay. Am J Hum Genet. 2019; 104(1) 164-78.

PubMed Abstract | Publisher Full Text | Free Full Text

28. Castermans $D$, Wilquet $V$, Parthoens $E$, et al:: The neurobeachin gene is disrupted by a translocation in a patient with idiopathic autism. $J$ Med Genet. 2003; 40(5): 352-6.

PubMed Abstract | Publisher Full Text | Free Full Text

29. F Calhoun JD, Carvill GL: Unravelling the genetic architecture of autosomal recessive epilepsy in the genomic era. J Neurogenet. 2018; 32(4): 295-312. PubMed Abstract | Publisher Full Text | F1000 Recommendation

30. F Murakami Y, Nguyen TTM, Baratang N, et al.: Mutations in PIGB Cause an Inherited GPI Biosynthesis Defect with an Axonal Neuropathy and Metabolic Abnormality in Severe Cases. Am J Hum Genet. 2019; 105(2): 384-94. PubMed Abstract | Publisher Full Text | Free Full Text | F1000 Recommendation

31. Abdel-Salam G, Thoenes M, Afifi HH, et al:: The supposed tumor suppressor gene WWOX is mutated in an early lethal microcephaly syndrome with epilepsy, growth retardation and retinal degeneration. Orphanet J Rare Dis. 2014; 9: 12 .

PubMed Abstract | Publisher Full Text | Free Full Text

32. Milh M, Falace A, Villeneuve N, et al.: Novel compound heterozygous mutations in TBC1D24 cause familial malignant migrating partial seizures of infancy. Hum Mutat. 2013; 34(6): 869-72.

PubMed Abstract | Publisher Full Text

33. Thevenon J, Milh M, Feillet F, et al:: Mutations in SLC13A5 cause autosomalrecessive epileptic encephalopathy with seizure onset in the first days of life. Am J Hum Genet. 2014; 95(1): 113-20.

PubMed Abstract | Publisher Full Text | Free Full Text

34. Muona M, Ishimura R, Laari A, et al.: Biallelic Variants in UBA5 Link Dysfunctional UFM1 Ubiquitin-like Modifier Pathway to Severe Infantile-Onset Encephalopathy. Am J Hum Genet. 2016; 99(3): 683-94. PubMed Abstract | Publisher Full Text | Free Full Text

35. Azaiez H, Booth KT, Bu F, et al:: TBC1D24 mutation causes autosomaldominant nonsyndromic hearing loss. Hum Mutat 2014; 35(7): 819-23. PubMed Abstract | Publisher Full Text | Free Full Text

36. $F$ Yang $C$, Zhang $Y$, Song $Z$, et al:: Novel compound heterozygous mutations in the WWOX gene cause early infantile epileptic encephalopathy. Int J Dev Neurosci. 2019; 79: 45-8.

PubMed Abstract | Publisher Full Text | F1000 Recommendation

37. Ehaideb SN, Al-Bu Ali MJ, Al-Obaid JJ, et al:: Novel Homozygous Mutation in the wWOX Gene Causes Seizures and Global Developmental Delay: Report and Review. Trans/ Neurosci. 2018; 9: 203-8. PubMed Abstract | Publisher Full Text | Free Full Text

38. F Oosterhof N, Chang IJ, Karimiani EG, et al:: Homozygous Mutations in CSF1R Cause a Pediatric-Onset Leukoencephalopathy and Can Result in Congenital Absence of Microglia. Am J Hum Genet. 2019; 104(5): 936-47. PubMed Abstract | Publisher Full Text | Free Full Text | F1000 Recommendation

39. F Monies D, Maddirevula S, Kurdi W, et al:: Autozygosity reveals recessive mutations and novel mechanisms in dominant genes: implications in variant interpretation. Genet Med. 2017; 19(10): 1144-50.

PubMed Abstract | Publisher Full Text | F1000 Recommendation

40. Epilepsy Phenome/Genome Project Epi4K Consortium: Copy number variant analysis from exome data in $\mathbf{3 4 9}$ patients with epileptic encephalopathy. Ann Neurol. 2015; 78(2): 323-8.

PubMed Abstract | Publisher Full Text | Free Full Text

41. Mefford HC, Yendle SC, Hsu C, et al.: Rare copy number variants are an important cause of epileptic encephalopathies. Ann Neurol. 2011; 70(6): 974-85. PubMed Abstract | Publisher Full Text | Free Full Text

42. Olson $\mathrm{H}$, Shen $\mathrm{Y}$, Avallone $\mathrm{J}$, et al:: Copy number variation plays an important role in clinical epilepsy. Ann Neurol. 2014; 75(6): 943-58. PubMed Abstract | Publisher Full Text | Free Full Text

43. F Orsini A, Zara F, Striano P: Recent advances in epilepsy genetics. Neurosci Lett. 2018; 667: 4-9. PubMed Abstract | Publisher Full Text | F1000 Recommendation

44. $\quad F$ Mingirulli N, Pyle A, Hathazi D, et al.: Clinical presentation and proteomic signature of patients with TANGO2 mutations. J Inherit Metab Dis. 2020; 43(2): 297-308.

PubMed Abstract | Publisher Full Text | F1000 Recommendation

45. Kremer LS, Distelmaier F, Alhaddad B, et al:: Bi-allelic Truncating Mutations in TANGO2 Cause Infancy-Onset Recurrent Metabolic Crises with Encephalocardiomyopathy. Am J Hum Genet. 2016; 98(2): 358-62. PubMed Abstract | Publisher Full Text | Free Full Text

46. Lalani SR, Liu P, Rosenfeld JA, et al:: Recurrent Muscle Weakness with Rhabdomyolysis, Metabolic Crises, and Cardiac Arrhythmia Due to Bi-allelic
TANGO2 Mutations. Am J Hum Genet. 2016; 98(2): 347-57.

PubMed Abstract | Publisher Full Text | Free Full Text

47. F Pfundt R, Del Rosario M, Vissers LELM, et al:: Detection of clinically relevant copy-number variants by exome sequencing in a large cohort of genetic disorders. Genet Med. 2017; 19(6): 667-75.

PubMed Abstract | Publisher Full Text | Free Full Text | F1000 Recommendation

48. Martin HC, Kim GE, Pagnamenta AT, et al.: Clinical whole-genome sequencing in severe early-onset epilepsy reveals new genes and improves molecular diagnosis. Hum Mol Genet. 2014; 23(12): 3200-11.

PubMed Abstract | Publisher Full Text | Free Full Text

49. F Perenthaler E, Yousefi S, Niggl E, et al:: Beyond the Exome: The Non-coding Genome and Enhancers in Neurodevelopmental Disorders and Malformations of Cortical Development. Front Cell Neurosci. 2019; 13: 352. PubMed Abstract | Publisher Full Text | Free Full Text | F1000 Recommendation

50. Mefford HC: The Road to Diagnosis: Shortening the Diagnostic Odyssey in Epilepsy. Epilepsy Curr. 2019; 19(5): 307-9.

PubMed Abstract | Publisher Full Text | Free Full Text

51. F Sánchez Fernández I, Loddenkemper T, Gaínza-Lein M, et al:: Diagnostic yield of genetic tests in epilepsy: A meta-analysis and cost-effectiveness study. Neurology. 2019; pii: 10.1212/WNL.0000000000006850. PubMed Abstract | Publisher Full Text | Free Full Text | F1000 Recommendation

52. F Snoeijen-Schouwenaars FM, van Ool JS, Verhoeven JS, et al:: Diagnostic exome sequencing in 100 consecutive patients with both epilepsy and intellectual disability. Epilepsia. 2019; 60(1): 155-64. PubMed Abstract | Publisher Full Text | F1000 Recommendation

53. F D'Gama AM, Walsh CA: Somatic mosaicism and neurodevelopmental disease. Nat Neurosci. 2018; 21(11): 1504-14. PubMed Abstract | Publisher Full Text | F1000 Recommendation

54. Ye Z, McQuillan L, Poduri A, et al:: Somatic mutation: The hidden genetics of brain malformations and focal epilepsies. Epilepsy Res. 2019; 155: 106161. PubMed Abstract | Publisher Full Text

55. F Acuna-Hidalgo R, Bo T, Kwint MP, et al.: Post-zygotic Point Mutations Are an Underrecognized Source of De Novo Genomic Variation. Am J Hum Genet. 2015; 97(1): 67-74

PubMed Abstract | Publisher Full Text | Free Full Text | F1000 Recommendation

56. Campbell IM, Yuan B, Robberecht $\mathrm{C}$, et al:: Parental somatic mosaicism is underrecognized and influences recurrence risk of genomic disorders. Am J Hum Genet. 2014; 95(2): 173-82.

PubMed Abstract | Publisher Full Text | Free Full Text

57. F Myers CT, Hollingsworth G, Muir AM, et al.: Parental Mosaicism in "De Novo" Epileptic Encephalopathies. N Engl J Med. 2018; 378(17): 1646-8. PubMed Abstract | Publisher Full Text | Free Full Text | F1000 Recommendation

58. F Stosser MB, Lindy AS, Butler E, et al:: High frequency of mosaic pathogenic variants in genes causing epilepsy-related neurodevelopmental disorders. Genet Med. 2018; 20(4): 403-10.

PubMed Abstract | Publisher Full Text | Free Full Text | F1000 Recommendation

59. Horsthemke B: Epimutations in human disease. Curr Top Microbiol Immunol. 2006; 310: 45-59.

PubMed Abstract | Publisher Full Text

60. Schuster J, Laan L, Klar J, et al:: Transcriptomes of Dravet syndrome iPSC derived GABAergic cells reveal dysregulated pathways for chromatin remodeling and neurodevelopment. Neurobiol Dis. 2019; 132: 104583. PubMed Abstract | Publisher Full Text

61. F LaCroix AJ, Stabley D, Sahraoui R, et al.: GGC Repeat Expansion and Exon 1 Methylation of XYLT1 Is a Common Pathogenic Variant in Baratela-Scott Syndrome. Am J Hum Genet. 2019; 104(1): 35-44.

PubMed Abstract | Publisher Full Text | Free Full Text | F1000 Recommendation

62. $\mathrm{F}$ Barbosa M, Joshi RS, Garg $\mathrm{P}$, et al:: Identification of rare de novo epigenetic variations in congenital disorders. Nat Commun. 2018; 9(1): 2064. PubMed Abstract | Publisher Full Text | Free Full Text | F1000 Recommendation

63. F Aref-Eshghi E, Bend EG, Colaiacovo S, et al:: Diagnostic Utility of Genomewide DNA Methylation Testing in Genetically Unsolved Individuals with Suspected Hereditary Conditions. Am J Hum Genet. 2019; 104(4): 685-700. PubMed Abstract | Publisher Full Text | Free Full Text | F1000 Recommendation

64. Feng $\mathrm{Y}$, Zhang $\mathrm{Y}$, Ying C, et al:: Nanopore-based fourth-generation DNA sequencing technology. Genomics Proteomics Bioinformatics. 2015; 13(1): 4-16. PubMed Abstract | Publisher Full Text | Free Full Text

65. Rhoads A, Au KF: PacBio Sequencing and Its Applications. Genomics Proteomics Bioinformatics. 2015; 13(5): 278-89. PubMed Abstract | Publisher Full Text | Free Full Text

66. Pareek CS, Smoczynski R, Tretyn A: Sequencing technologies and genome sequencing. J Appl Genet. 2011; 52(4): 413-35. PubMed Abstract | Publisher Full Text | Free Full Text

67. F Nakano K, Shiroma A, Shimoji M, et al:: Advantages of genome sequencing by long-read sequencer using SMRT technology in medical area. Hum Cell. 2017; 30(3): 149-61.

PubMed Abstract | Publisher Full Text | Free Full Text | F1000 Recommendation 


\section{Open Peer Review}

\section{Current Peer Review Status:}

\section{Editorial Note on the Review Process}

Faculty Reviews are review articles written by the prestigious Members of Faculty Opinions. The articles are commissioned and peer reviewed before publication to ensure that the final, published version is comprehensive and accessible. The reviewers who approved the final version are listed with their names and affiliations.

\section{The reviewers who approved this article are:}

\section{Version 1}

\section{Weiping Liao}

Institute of Neuroscience and the Second Affiliated Hospital of Guangzhou Medical University, Guangzhou, China

Competing Interests: No competing interests were disclosed.

\section{Josemir W. Sander}

NIHR University College London Hospitals Biomedical Research Centre, UCL Queen Square Institute of Neurology, London, UK

Competing Interests: No competing interests were disclosed.

The benefits of publishing with F1000Research:

- Your article is published within days, with no editorial bias

- You can publish traditional articles, null/negative results, case reports, data notes and more

- The peer review process is transparent and collaborative

- Your article is indexed in PubMed after passing peer review

- Dedicated customer support at every stage

For pre-submission enquiries, contact research@f1000.com

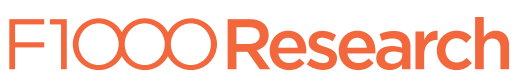

